\title{
Role of the Cyclosporin-sensitive Transcription Factor NFAT1 in the Allergic Response
}

\author{
João PB Viola, Anjana Rao ${ }^{+}$
}

The Center for Blood Research and the Department of Pathology, Harvard Medical School, 200 Longwood Ave., Boston, MA 02115, USA

Proteins belonging to the NFAT (nuclear factor of activated T cells) family of transcription factors are expressed in most immune cell types, and play a central role in the transcription of cytokine genes, such as IL-2, IL-4, IL-5, IL-13,IFN- $\gamma, T N F-\alpha$, and GM-CSF. The activity of NFAT proteins is regulated by the calcium/calmodulin-dependent phosphatase calcineurin, a target for inhibition by CsA and FK506. Recently, two different groups have described that mice lacking the NFAT1 transcription factor show an enhanced immune response, with tendency towards the development of a late Th2-like response. This review evaluates the possible role of NFAT proteins in the Th2 immune response and in the eosinophilmediated allergic response.

Key words: nuclear factor of activated T cells - interleukin - cyclosporin

The cytokine profiles of $\mathrm{T}$ cells differentiating down the Th1 and Th2 pathways have been described, Th1 cells preferentially produce IL- 2 and IFN- $\gamma$, whereas Th2 cells produce IL-4, IL-5, IL10 and IL-13 (Paul \& Seder 1994, Carter \& Dutton 1996). In many pathological situations, the balance between Th1 and Th2 immune response determines the outcome of different immunologically-mediated clinical syndromes including infectious, autoimmune, and allergic diseases (Carter \& Dutton 1996).

Allergic disease is a broad range of disorders including rhinitis, conjunctivitis, systemic anaphylaxis, and asthma (Casolaro et al. 1996, Drazen et al. 1996). Atopic allergy is characterized by increased synthesis of IgE antibodies through the actions of IL-4 and IL-13 in B cell Ig isotype class switching, directed at groups of antigens that activate the CD4-dependent Th2-like immune response (Romagnani 1995). The IgE produced binds to Fce receptors present on the surface of mast cells and basophils, priming them for activation by antigen, and triggers the release of vasoactive mediators, chemotactic factors and cytokines (Romagnani 1995, Drazen et al. 1996). In addition, eosinophils are also involved in the pathogenesis of allergic reactions, as these cells accumulate at the sites of allergic inflammation and significantly contribute to the tissue damage (Desreumaux \& Capron 1996).

\footnotetext{
${ }^{+}$Corresponding author. Fax: +617-278.3280. E-mail: arao@cbr.med.harvard.edu Received 3 September 1997 Accepted 30 September 1997
}

In asthma, some data suggest that the severity of the disease is related to the degree of inflammation (Peters 1990, Broide et al. 1991, Pare \& Bai 1995), and that the magnitude of the asthmatic response is related to the number of eosinophils present in the lung (Bradley et al. 1991). Moreover, suppression of eosinophil accumulation at the site of inflammation impairs the development of asthma disease (Wagner et al. 1990, Foster et al. 1995). These data suggest that eosinophils could be a central mediator of the pathogenesis of allergic disease. We can hypothesize three sequential and interacting events for how eosinophils mediate inflammation at the site of allergic response, described as follows: first, eosinophil differentiation and maturation in the bone marrow; second, rolling, adhesion, and migration in the inflamed vascular endothelium; and third, activation and degranulation in the target organ (Fig. 1).

Eosinophil tissue infiltration is coordinated by an interacting network of cytokines, chemokines, adhesion molecules, and inflammatory mediators. In fact, GM-CSF, IL-3 and IL-5 have been described as factors that induce differentiation, maturation and proliferation of bone marrow eosinophils (Sanderson et al. 1985, Lopez et al. 1986, Clutterbuck \& Sanderson 1988, Takatsu et al. 1988, Warren \& Morre 1988, Yamaguchi et al. 1988). However, blood eosinophilia is not related to eosinophil tissue accumulation (Dent et al. 1990, Desreumaux et al. 1996), suggesting that overproduction of eosinophils is not enough for tissue infiltration by these cells, and chemoattractant production at the site of inflammation is essential for eosinophil recruitment. 


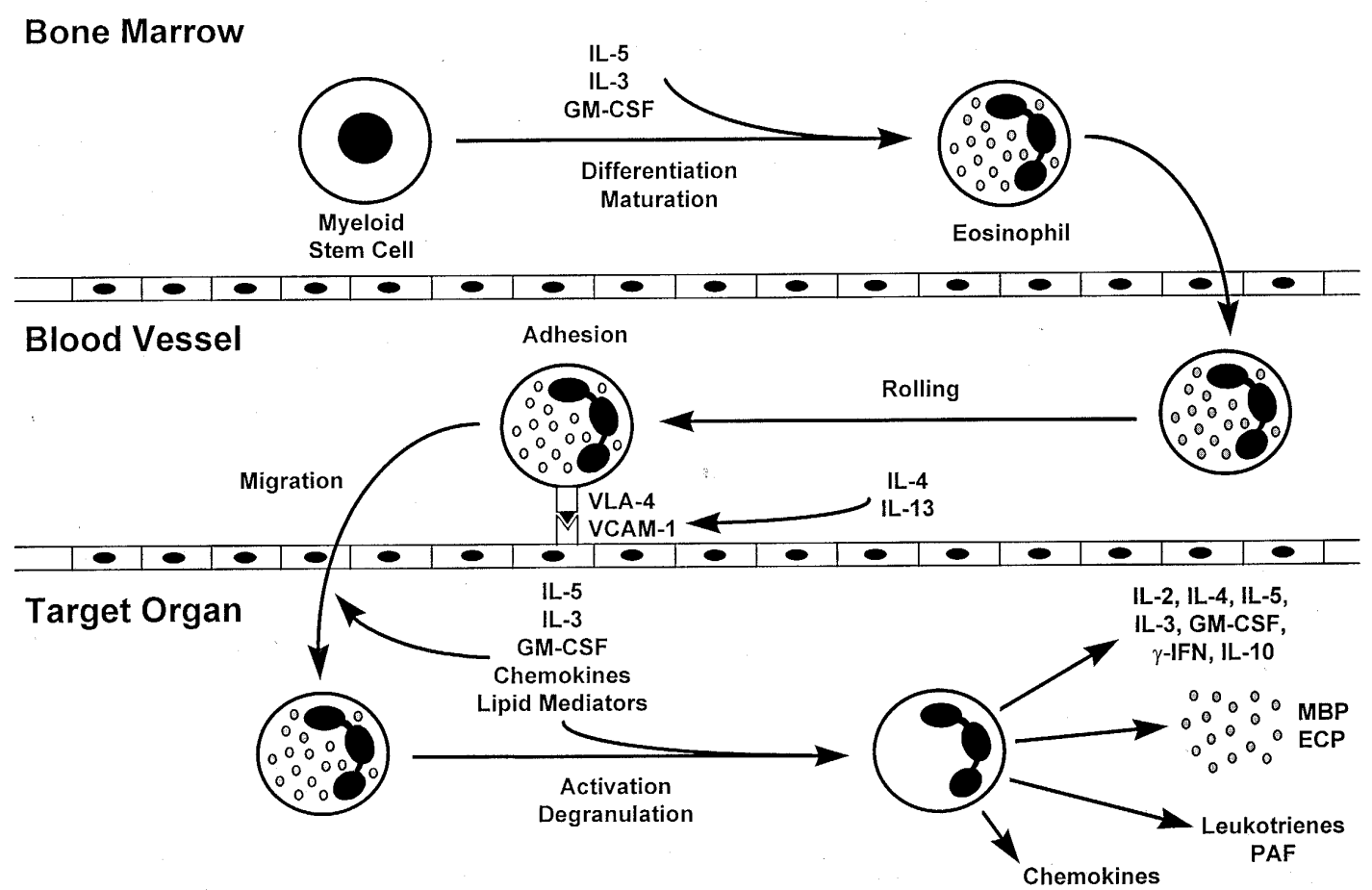

Fig. 1: a simplified view of eosinophil differentiation and maturation, in the bone marrow; rolling, adhesion and migration, in the blood vessel; and activation and degranulation, in the target organ. Cytokines, growth factors, adhesion molecules, chemokines, and lipid mediators that play a role in each step are indicated.

Rolling and adhesion of eosinophils on vascular endothelium is the first step for eosinophil infiltration in the target organ, and may depend on several adhesion molecules (Desreumaux \& Capron 1996). However, eosinophils are the only granulocytes that express VLA-4, and may selectively bind to endothelial cells via VCAM-1 (Weller et al. 1991, Pretolani et al. 1994, Nakajima et al. 1994, Wardlaw et al. 1994). Moreover, it has been described that IL-4 and IL-13 upregulate VCAM-1 on human endothelial cells (Bochner et al. 1995), suggesting that interaction between VLA-4/VCAM-1 play a central role in eosinophil migration during the allergic response.

Eosinophil migration into inflamed tissue involves several chemoattractant mediators, including cytokines, chemokines and lipid mediators, and occurs after adhesion to the vascular endothelium (Desreumaux \& Capron 1996). GM-CSF, IL-3 and IL-5, are the key cytokines influencing eosinophil migration and activation (Broide et al. 1992, Weller 1993, Sullivan \& Broide 1996). In fact, several reports demonstrated that IL-5 plays the central role in eosinophil-mediated allergic responses, since this cytokine is a selective chemoatractant for eosinophils (Sehmi et al. 1992), and has the ability to prime and activate these cells (Coeffier et al. 1991, Sehmi et al. 1992, Warringa et al. 1992). In addition, IL-5 deficient mice do not show eosinophilia (Kopf et al. 1996), and fail to develop airway hyperresponsiveness and eosinophil infiltration in an experimental model of asthma (Foster et al. 1995). Other important chemoattractants and activators of eosinophils are the $\mathrm{C}$-C subfamily of chemokines (Desreumaux \& Capron 1996). The eosinophil active chemokines include RANTES, MCP-2, MCP-3, MCP-4, MCP-5, MIP-1 $\alpha$, and eotaxin (Jia et al. 1996, Kita \& Gleich 1996, Sarafi et al. 1997). Eotaxin, first described in guinea pigs and subsequently in mice and humans, is a potent and specific eosinophil chemoattractant (Jose et al. 1994, Gonzalo et al. 1996, Ponath et al. 1996), and disruption of the eotaxin gene partially reduces tissue eosinophil infiltration in a model of allergic response (Rothenberg et al. 1997).

Once eosinophils infiltrate the inflamed tissue, they degranulate and secrete several proinflamatory mediators and cytokines (Weller 1993). Activated eosinophils release their granule proteins, including the major basic proteins, eosinophil peroxidase (EPO), eosinophil cationic protein (ECP), and eosinophil-derived neurotoxin (Desreumaux \& Capron 
1996). They also secrete lipid mediators, chemokines, and cytokines, which amplify the response and generate a feedback loop that perpetuates the allergic inflammatory response (Drazen et al. 1996). Together, these inflammatory mediators and cytokines generate tissue damage that could be related with the clinical symptoms of the different allergic diseases.

\section{NFAT TRANSCRIPTION FACTORS IN IMMUNE RE- SPONSE}

Many of the cytokines that regulate eosinophil function are under the control of proteins belonging to the NFAT (nuclear factor of activated T cells) family of transcription factors. These proteins play a key role in the regulation of cytokine gene transcription during the immune response (Crabtree \& Clipstone 1994, Rao 1994, Jain et al. 1995b). The NFAT family encodes four distinct classes of proteins: NFAT1 (formerly NFATp), NFAT2 (NFATc), NFAT3 and NFAT4 (NFATx) (Rao et al. 1997). NFAT1, the first identified member of the family, was cloned from murine (Ar-5) and human (Jurkat) T cell cDNA libraries (McCaffrey et al. 1993, Luo et al. 1996). A distinct protein, NFATc (NFAT2), later was also cloned from a Jurkat T cell cDNA library (Northrop et al. 1994). cDNA clones encoding three other NFAT proteins: NFAT3, NFAT4 and NFATx (isoform of NFAT4), were isolated from Jurkat T cell, human peripheral blood (PBL) and human thymus cDNA libraries (Ho et al. 1995, Masuda et al. 1995).

Despite their name, NFAT proteins are expressed not only in T cells, but also in other classes of immune and non-immune cells. At the protein level, NFAT1 and NFAT2 are expressed in peripheral $\mathrm{T}$ cells and $\mathrm{T}$ cell lines, and NFAT1 is also expressed in B cells, mast cells, NK cells, monocytes and macrophages (Ho et al. 1994, Aramburu et al. 1995, Ruff \& Leach 1995, Wang et al. 1995, Weiss et al. 1996). Moreover, NFAT1 is expressed in a neuronal cell line and in the nervous system (Ho et al. 1994), and an endothelial cell line (Cockerill et al. 1995a, Wang et al. 1995). NFAT1 and NFAT2 mRNAs are expressed in peripheral lymphoid tissue (spleen and PBL), and NFAT2 mRNA is upregulated in activated T cells and NK cells (Northrop et al. 1994, Aramburu et al. 1995, Hoey et al. 1995, Masuda et al. 1995, Park et al. 1996). NFAT4 mRNA is expressed at high levels in the thymus (Hoey et al. 1995, Ho et al. 1995, Masuda et al. 1995), and NFAT3 is expressed at low levels in lymphoid tissues (Hoey et al. 1995).

Several isoforms have been described for NFAT1, NFAT2 and NFAT4. Sequence homology represented in all the isoforms suggests two different domains, comprising the DNA-binding do- main (DBD) and the NFAT homology region (NHR) (Jain et al. 1995a, Luo et al. 1996). The $\mathrm{DBD}$, which is located between amino acid residues 400 and 700, is highly conserved within the NFAT family, and shows moderate sequence similarity to the DNA-binding domains of Rel-family proteins (Nolan 1994, Jain et al. 1995a, Chytil \& Verdine 1996). This domain contains the highly conserved RAHYETEG sequence in which residues contact DNA (Jain et al. 1995a, Chytil \& Verdine 1996). The NHR is located in the N-terminal region, comprising 300 amino acids, and shows a strong conservation of several sequence motifs characteristic of the NFAT family (Ho et al. 1995, Hoey et al. 1995, Masuda et al. 1995, Luo et al. 1996) (Fig. 2).

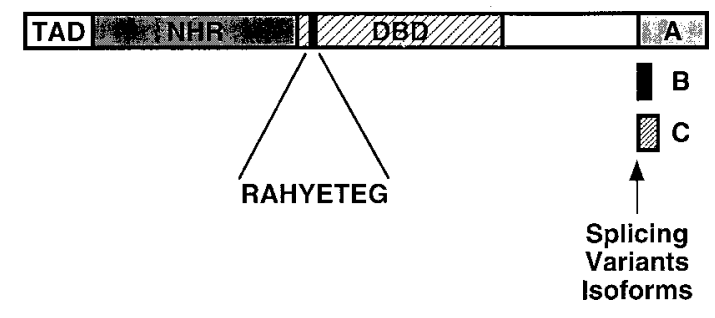

Fig. 2: schematic diagram of the primary structure of the NFAT1 protein, as deduced from analysis of cDNA clones. The region of highest homology within NFAT proteins is the DNA-binding domain (DBD), which shows similarity to the Rel homology region of Rel-family transcription factors, and encodes the amino acids that contact DNA. Other regions such as transactivation domain (TAD), NFAT homology region (NHR), and splicing variants isoforms are indicated.

NFAT transcription factors are cytosolic proteins constitutively expressed in resting cells (Rao et al. 1997). NFAT proteins are activated by stimulation of receptors coupled to calcium mobilization, such as the antigen receptors on $\mathrm{T}$ and $\mathrm{B}$ cells (Yaseen et al. 1993, Choi et al. 1994, Crabtree \& Clipstone 1994, Rao, 1994, Venkataraman et al. 1994, Jain et al. 1995b, Serfling et al. 1995, Loh et al. 1996b), Fce receptors on mast cells and basophils (Hutchinson \& McCloskey 1995, Prieschl et al. 1995a, Weiss et al. 1996), the Fc $\gamma$ receptors on macrophages and NK cells (Aramburu et al. 1995), and receptors coupled to heterotrimeric $\mathrm{G}$ proteins (Desai et al. 1990, Wu et al. 1995, Boss et al. 1996). Three different steps of activation have been defined for NFAT proteins: dephosphorylation, nuclear translocation, and DNA binding. In resting cells, NFAT proteins are phosphorylated and cytoplasmic, and show a low affinity for DNA (Shaw et al. 1995). Stimuli that trigger calcium mobilization result in rapid dephosphorylation of 
NFAT proteins and their translocation to the nucleus, and dephosphorylated proteins show increased affinity for DNA (Shaw et al. 1995, Loh et al. 1996a,b). Receptor stimulation and calcium mobilization result in activation of the calmodulindependent phosphatase calcineurin (Weiss \& Littman 1994). Each step of NFAT activation is blocked by the calcineurin inhibitors CsA or FK506, suggesting that calcineurin is a major upstream regulator of NFAT proteins, and that dephosphorylation is the initial step of NFAT activation (Fig. 3).

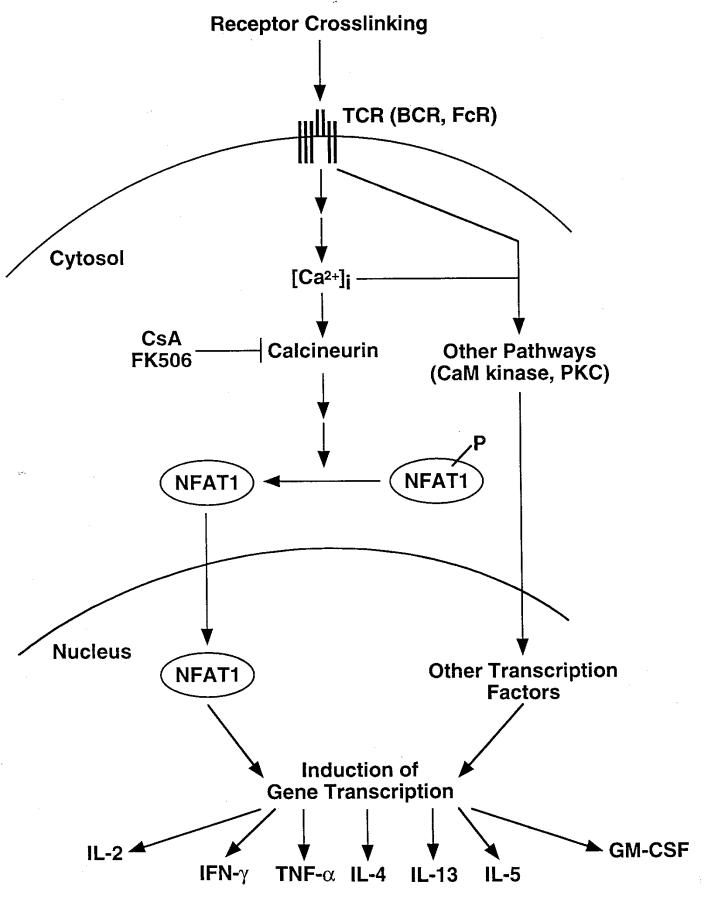

Fig. 3: signal transduction mechanisms leading to transcription of cytokine genes in activated T cells (and other cells of the immune system) upon stimulation through surface receptors capable of mobilizing calcium. Abbreviations: TCR, T-cell receptor; BCR, B-cell receptor; FcR, Fc $\gamma$ and Fce receptors; CsA, cyclosporin A; PKC, protein kinase $\mathrm{C}$; $\mathrm{CaM}$ kinase, calmodulindependent kinase; $\mathrm{P}$, phosphorylation.

Stimulated cells inducibly transcribe a large number of genes, such as genes encoding transcription factors, signalling proteins, cytokines, cell surface receptors, and other effector proteins (Leonard et al. 1987, Crabtree 1989, Cockerill et al. 1995b, Kelly \& Siebenlist 1995). NFAT was first identified in T cells as a rapidly-inducible nuclear factor binding to the distal antigen receptor response element of the human IL-2 promoter (Shaw et al. 1988). Over the next few years, studies from several laborato- ries indicated that the promoter/enhancer regions of different activation genes possessed binding sites for NFAT family proteins, including the cytokines IL-2 (Shaw et al. 1988, Mattila et al. 1990, Randak et al. 1990, Brabletz et al. 1991, Ullman et al. 1991, Jain et al. 1993a, Rooney et al. 1995a), IL-4 (Casalaro et al. 1995, Rooney et al. 1995b), IL-5 (Prieschl et al. 1995a,b), IL-13 (Dolganov et al. 1996), IFN- $\gamma($ Brown et al. 1991, Campbell et al. 1996), TNF- $\alpha$ (McCaffrey et al. 1994, Tsai et al. 1996), and GM-CSF(Cockerill et al. 1995a,b), as well as the cell surface receptors CD40L (Schubert et al. 1995, Tsytsykova et al. 1996), and CTLA-4 (Perkins et al. 1996). Based on comparison of these sequences, the NFAT binding site is presented as a 9 bp element, possessing the consensus sequence (A/T)GGAAA(A/N)(A/T/C)N (Rao et al. 1997). In addition, NFAT proteins show a characteristic ability to cooperate with AP-1 proteins in DNA-binding and transactivation (Rao 1994). The interaction between NFAT proteins and AP-1 involves binding of these transcription factors to adjacent sites on DNA, and results in stabilisation of the NFAT-DNA interaction (Jain et al. 1993a,b, Chen et al. 1995). Note that cytokines that are inhibited by CsA or FK506 have present in their promoter regions binding sites for NFAT proteins, suggesting that NFAT transcription factors are major targets of these immunosuppressive drugs (Rao et al. 1997).

Cytokine expression by different cells of the immune system plays a central role in the immune response, and each cell type produces a characteristic pattern of cytokines (Paul \& Seder 1994). The immune response is coordinated by an interacting network of transcription factors that dictate expression of different cytokines (Crabtree 1989, Paul \& Seder 1994). To study the unique functions of the NFAT1 transcription factor in the in vivo immune response, two different groups generated mutant mice carrying a disrupted NFAT1 gene (Hodge et al. 1996, Xanthoudakis et al. 1996). Although all reports indicate that the NFAT1 transcription factor is a positive regulator of cytokine expression, surprisingly, certain primary and secondary immune responses in mice lacking NFAT1 gene were enhanced, such as increased intrapleural accumulation of eosinophils and increased serum IgE levels in an in vivo model of allergic inflammation (Xanthoudakis et al. 1996), increased serum IgE levels in response to immunization with TNP-ovalbumin (Hodge et al. 1996), and more efficient differentiation towards a Th2 phenotype in spleen cells stimulated in vitro with IL-4 and anti-CD3 (Hodge et al. 1996). In the next section we discuss the possible role of the NFAT1 transcription factor in the Th2 immune response and eosinophil-mediated allergic inflammation. 
ROLE OF NFAT1 TRANSCRIPTION FACTOR IN THE ALLERGIC RESPONSE

The response of the immune system to antigen is coordinated by an interacting network of transcription factors that dictate expression of different effector proteins that regulate the immune response (Crabtree 1989, Paul \& Seder 1994). However, it is not known how the same stimuli can be responsible for encoding the specificity of cellular response. Recently, it has been described that different calcium signalling patterns can activate different transcription factors, demonstrating that the same second messenger can drive specificity in signalling to the nucleus (Dolmetsch et al. 1997). Nevertheless, the molecular basis for the tissuespecific expression of Th1/Th2-like cytokines has remained elusive. Over the next few years, several groups have been described important advances in signaling and gene transcription in the immune system using in vivo gene disruption.

In other to address the specialized functions of NFAT1 transcription factor in the in vivo immune response, mutant mice carrying a disrupted NFAT1 gene have been described (Hodge et al. 1996, Xanthoudakis et al. 1996). In both cases the targeted exon was in the DNA-binding domain encoding the Rel-homology region (see above), and the disruption resulted either in the expression of a truncated protein without DNA-binding activity (Hodge et al. 1996), or in no protein expression (null phenotype) (Xanthoudakis et al. 1996). Except for a moderate degree of splenomegaly, NFAT1-deficient mice developed normally, did not exhibit any obvious behavioral deficiencies, and were immunocompetent.

In the primary immune response, NFAT1-deficient mice showed no impairment in IL-2, IL-4, IFN- $\gamma$ and TNF- $\alpha$ production by in vitro stimulation of spleen cells with anti-CD3 antibody or Con A (Xanthoudakis et al. 1996). However, in an in vivo model of primary response NFAT1-deficient mice showed an early impairment of several cytokines, such as IL-4, IL-13, TNF- $\alpha$ and GMCSF, and cell surface receptors, including CD40L and FasL (Hodge et al. 1996). These results suggest that the NFAT1 protein played an important role in the primary in vivo immune response that could not have been predicted from the in vitro experiments.

Surprisingly, certain primary and secondary immune responses were markedly enhanced. In fact, CD4 T cells hyperproliferated in an in vitro response to anti-CD3 antibody, and an in vitro model of $\mathrm{T}$ helper (Th) differentiation, NFAT1deficient mice showed an increased level of IL-4 production at later timepoints (Hodge et al. 1996).
In addition, these mice presented high serum IgE levels in response to immunization with ovalbumin (Hodge et al. 1996, Xanthoudakis et al. 1996). Moreover, NFAT1-deficient mice consistently showed a marked increase in the secondary immune response using two different experimental models. First, cells from draining lymph nodes of mice that had been sensitized with ovalbumin hyperproliferated after a secondary in vitro stimulation with the same antigen (Xanthoudakis et al. 1996). Second, an allergic/inflammatory response to antigen was assessed in vivo. Mice that had been previously sensitized to ovalbumin were restimulated by intrapleural injection of antigen, and the accumulation of eosinophils in the pleural cavity was assessed. NFAT-deficient mice showed a marked increased in the number of eosinophils in the pleural cavity and a corresponding increase in the level of serum IgE (Xanthoudakis et al. 1996).

The immune phenotype of NFAT1-deficient mice illustrates three important points. First, these mice are immunocompetent rather than immunodeficient and do not show any gross impairment in the production of NFAT-dependent cytokines, indicating that the lack of NFAT1 is compensated for by the presence of other NFAT proteins. Second, the increased secondary immune responses and increased cell proliferation observed in NFAT1-deficient mice suggests that NFAT1 may actually have an overall negative effect on immune responsiveness in normal mice. This behaviour is not unprecedented: for example, in signal transduction pathways, kinases that are activated early during a response often activate feedback processes that contribute to the late downregulation of the same response. Finally, the unusual hyper-eosinophila of NFAT1-deficient mice in a model of allergy, and their tendency towards the late production of Th2type cytokines, suggests that NFAT1 critically influences Th differentiation during the normal immune response. NFAT1 could act to promote the transcription of genes encoding immunosuppressive cytokines, cytokines that skew T cell differentiation towards the Th1 pathway, or cytokines that suppress differentiation towards the Th2 pathway. Alternatively, NFAT1 could inhibit the production of cytokines having the opposite effect. These possibilities are not mutually exclusive. Given the importance of Th1-Th2 cytokine production in asthma, allergy, and other clinical situations, it is of considerable interest to understand the mechanisms by which NFAT1 exerts its profound effects on T cell differentiation and function.

\section{ACKNOWLEDGMENTS}

To Drs Patricia Bozza and Heidi Okamura for critical reading of this manuscript. Work in the A Rao labo- 
ratory was supported by grants from National Institute of Health and Hoffman-La Roche, Inc.

\section{REFERENCES}

Aramburu J, Azzoni L, Rao A, Perussia B 1995. Activation and expression of the nuclear factor of activated T cells, NFATp and NFATc, in human natural killer cells: regulation upon CD16 ligand binding. J Exp Med 182: 801-810.

Bochner BS, Klunk DA, Sterbinsky SA, Coffman RL, Schleimer RP 1995. IL-13 selectively induces vascular cell adhesion molecule-1 expression in human endothelial cells. J Immunol 154: 799-803.

Boss V, Talpade DJ, Murphy TJ 1996. Induction of NFAT-mediated transcription by Gq-coupled receptors in lymphoid and non-lymphoid cells. $J$ Biol Chem 271: 10429-10432.

Brabletz T, Pietrowski I, Serfling E 1991. The immunosuppressives FK506 and cyclosporin A inhibit the generation of protein factors binding to the two purine boxes of the interleukin 2 enhancer. Nucleic Acids Res 19: 61-67.

Bradley BL, Azzawi M, Jacobson M, Assoufi B, Collins JV, Irani AMA, Schwartz LB, Durham SR, Jeffrey PK, Kay AB 1991. Eosinophils, T-lymphocytes, mast cells, neutrophils and macrophages in bronchial biopsy specimens from atopic subjects with asthma: comparison with biopsy speciments from atopic subjects without asthma and control subjects and relationship to bronchial hyperresponsiveness. J Allergy Clin Immunol 88: 661-670.

Broide DH, Gleich GJ, Cuomo AJ, Coburn DA, Federman LB, Schwartz LB, Wasserman SI 1991. Evidence of ongoing mast cells and eosinophil degranulation in symptomatic asthma airway. J Allergy Clin Immunol 88: 637-648.

Broide DH, Paine MM, Firestein GS 1992. Eosinophils express interleukin 5 and granulocyte macrophagecolony-stimulating factor mRNA at sites of allergic inflammation in asthmatics. J Clin Invest 90: 14141424.

Brown DA, Nelson FB, Reinherz EL, Diamond DJ 1991. The human interferon- $\gamma$ gene contains an inducible promoter that can be transactivated by tax I and II. Eur J Immunol 21: 1879-1885.

Campbell PM, Pimm J, Ramassar V, Halloran PF 1996. Identification of a calcium-inducible, cyclosporinesensitive element in the IFN-g promoter that is a potential NFAT binding site. Transplantation 61: 933-939.

Carter LL, Dutton RW 1996. Type 1 and type 2: a fundamental dichotomoy for all T-cell subsets. Curr Opin Immunol 8: 336-342.

Casolaro V, Georas SN, Song Z, Zubkoff ID, Abdulkadir SA, Thanos D, Ono SJ 1995. Inhibition of NF-ATdependent transcription by NF-kB: implications for differential gene expression in T helper cell subsets. Proc Natl Acad Sci USA 92: 11623-11627.

Casolaro V, Georas SN, Song Z, Ono SJ 1996. Biology and genetics of atopic disease. Curr Opin Immunol 8: 796-803.

Chen L, Oakley MG, Glover JNM, Jain J, Dervan PB,
Hogan PG, Rao A, Verdine GL 1995. Only one of the two DNA-bound orientations of AP-1 found in solution cooperates with NFATp. Current Biology 5: 882-889.

Choi MSK, Brines RD, Holman MJ, Klaus GGB 1994. Induction of NF-AT in normal B lymphocytes by anti-immunoglobulin or CD40 ligand in conjunction with IL-4. Immunity 1: 179-187.

Chytil M, Verdine GL 1996. The Rel family of eukaryotic transcription factors. Curr Opin Struct Biol 6: 91-100.

Clutterbuck EJ, Sanderson CJ 1988. Human eosinophil hematopoiesis studied in vitro by means of murine eosinophil differntiation factor (IL-5): production of functionally active eosinophils from normal human bone marrow. Blood 71: 646-651.

Cockerill GW, Bert AG, Ryan GR, Gamble JR, Vadas MA, Cockerill PN 1995a. Regulation of granulocyte-macrophage colony-stimulating factor and Eselectin expression in endothelial cells by cyclosporin A and the T-cell transcription factor NFAT. Blood 86: 2689-2698.

Cockerill PN, Bert AG, Jenkins F, Ryan GR, Shannon MF, Vadas MA 1995b. Human granulocyte-macrophage colony-stimulating factor enhancer function is associated with cooperative interactions between AP-1 and NFATp/c. Mol Cell Biol 15: 2071-2079.

Coffier E, Joseph D, Vergaftig BB 1991. Activation of guinea pig eosinophils by human reconbinant IL-5. Selective priming to platelet-activating factor-acether and interference of its antagonists. J Immunol 147: 2595-2602.

Crabtree GR 1989. Contingent genetic regulatory events in T lymphocyte activation. Science 243: 355-361.

Crabtree GR, Clipstone NA 1994. Signal transmission between the plasma membrane and nucleus of $\mathrm{T}$ lymphocytes. Annu Rev Biochem 63: 1045-1083.

Dent LA, Strath M, Mellor AL, Sanderson CJ 1990. Eosinophilia in transgenic mice expressing interleukin 5. J Exp Med 172: 1425-1431.

Desai DM, Newton ME, Kadlecek T, Weiss A 1990. Stimulation of the phosphatidylinositol pathway can induce T-cell activation. Nature 348: 66-69.

Desreumaux P, Bloget F, Seguy D, Capron M, Cortot A, Colombel JF, Janin A 1996. Interlukin-3, granulocyte macrophage-colony stimulating factor and interleukin-5 synthesis in eosinophilic gastroenteritis. Gastroenterology 110: 768-774.

Desreumaux P, Capron M 1996. Eosinophils in alergic reactions. Curr Opin Immunol 8: 790-795.

Drazen JM, Arm JP, Austen KF 1996. Sorting out the cytokines of asthma. J Exp Med 183: 1-5.

Dolganov G, Bort S, Lovett M, Burr J, Schubert L, Short D, McGurn M, Gibson C, Lewis DB 1996. Coexpression of the interleukin-13 and interleukin4 genes correlates with their physical linkage in the cytokine gene cluster on human chromosome 5 q2331. Blood 87: 3316-3326.

Dolmetsch RE, Lewis RS, Goodnow CC, Healy JI 1997. Differential activation of transcription factors induced by $\mathrm{Ca}^{2+}$ response amplitude and duration. Nature 386: 855-858. 
Foster PS, Hogan SP, Ramsay AJ, Matthaei KI, Young IG 1995. IL-5 deficiency abolishes eosinophilia, airways hyperreactivity, and lung damage in a mouse asthma model. J Exp Med 183: 195-201.

Gonzalo JA, Jia GQ, Aguirre V, Friend D, Coyle AJ, Jenkins NA, Lin GS, Katz H, Lichtman A, Copeland N, Kopf M, Gutierrez-Ramos JC 1996. Mouse eotaxin expression parallels eosinophil accumulation during lung allergic inflammation but not restricted to a Th2-type response. Immunity 4: 1-14.

Ho AM, Jain J, Rao A, Hogan PG 1994. Expression of the transcription factor NFATp in a neuronal cell line and in the murine nervous system. J Biol Chem 269: 28181-28186.

Ho SN, Thomas DJ, Timmerman LA, Li X, Francke U, Crabtree GR 1995. NFATc3, a lymphoid-specific NFATc family member that is calcium-regulated and exhibits distinct DNA binding specificity. $\mathrm{J}$ Biol Chem 270: 19898-19907.

Hodge MR, Ranger AM, de la Brousse FC, Hoey T, Grusby M, Glimcher LH 1996. Hyperproliferation and dysregulation of IL-4 expression in NF-ATpdeficient mice. Immunity 4: 397-405.

Hoey T, Sun Y-L, Williamson K, Xu X 1995. Isolation of two new members of the NFAT gene family and functional characterization of the NFAT proteins. Immunity 4: 461-472.

Hutchinson LE, McCloskey MA 1995. FceRI-mediated induction of nuclear factor of activated T-cells. $J$ Biol Chem 270: 16333-16338.

Jain J, Miner Z, Rao A 1993a. Analysis of the preexisting and nuclear forms of nuclear factor of activated T cells. J Immunol 151: 837-848.

Jain J, McCaffrey PG, Miner Z, Kerppola TK, Lambert JN, Verdine GL, Curran T, Rao A 1993b. The T-cell transcription factor NFATp is a substrate for calcineurin and interacts with Fos and Jun. Nature 365: 352-355.

Jain J, Burgeon E, Badalian TM, Hogan PG, Rao A 1995a. A similar DNA-binding motif in NFAT family proteins and the Rel homology region. $\mathrm{J} \mathrm{Biol}$ Chem 270: 4138-4145.

Jain J, Loh C, Rao A 1995b. Transcriptional regulation of the interleukin 2 gene. Curr Opin Immunol 7: 333342.

Jia GQ, Gonzalo JA, Lloyd C, Kremer L, Lu L, Martinez C, Wershil BK, Gutierrez-Ramos JC 1996. Distinct expression and function of the novel mouse chemokine monocyte chemotactic protein-5 in lung allergic inflammation. J Exp Med 184: 1939-1951.

Jose PJ, Griffiths-Johnson DA, Collins PD, Walsh DT, Moqbel R, Totty NF, Truong O, Hsuan JJ, Williams TJ 1994. Eotaxin: a potent eosinophil chemoattractant cytokine detected in guinea-pig model of allergic airways inflammation. J Exp Med 179: 881-887.

Kelly K, Siebenlist U.1995. Immediate-early genes induced by antigen receptor stimulation. Curr Opin Immunol 7: 327-332.

Kita H and Gleich GJ. 1996. Chemokines active on eosinophils - potentials roles in allergic inflammation. $J$ Exp Med 183: 2421-2426.

Kopf M, Brombacher F, Hodgkin PD, Ramsay AJ,
Milbourne EA, Dai WJ, Ovington KS, Behm CA, Kohler G, Young IG, Matthaei KI 1996. IL-5-deficient mice have a development defect in CD5 B-1 cells and lack eosinophilia but have normal antibody and cytotoxic T cell response. Immunity 4: 15-24.

Leonard DG, Ziff EB, Greene LA 1987. Identification and characterization of mRNAs regulated by nerve growth factor in PC12 cells. Mol Cell Biol 7: 31563167.

Loh C, Shaw KTY, Carew J, Viola JPB, Luo C, Perrino BA, Rao A 1996a. Calcineurin binds the transcription factor NFAT1 and reversibly regulates its activity. J Biol Chem 271: 10884-10891.

Loh C, Carew JA, Kim J, Hogan PG, Rao A 1996b. Tcell receptor stimulation elicits an early phase of activation and a later phase of deactivation of the transcription factor NFAT1. Mol Cell Biol 16: 39453954.

Luo C, Burgeon E, Carew JA, Badalian TM, McCaffrey PG, Lane WS, Hogan PG, Rao A 1996. Recombinant NFAT1 (NFATp) is regulated by calcineurin in $\mathrm{T}$ cells and mediates the transcription of several cytokine genes. Mol Cell Biol 16: 3955-3966.

Lopez AF, Begley CG, Williamson DJ, Warren DJ, Vadas MA, Sanderson CJ 1986. Murine eosinophils differentiation factor: an eosinophil-specific colonystimulating factor with activity for human cells. $J$ Exp Med 163: 1085-1099.

Mattila PS, Ullman KS, Fiering S, Emmel EA, McCutcheon M, Crabtree GR, Herzenberg LA 1990. The action of cyclosporin A and FK506 suggest a novel step in the activation of T lymphocytes. EMBO J 9: 4425-4433.

Masuda E, Naito Y, Tokumitsu H, Campbell D, Saito F, Hannum C, Arai K-I, Arai N 1995. NFATx, a novel member of the NFAT family that is expressed predominantly in the thymus. Mol Cell Biol 15: 26972706.

McCaffrey PG, Luo C, Kerppola TK, Jain J, Badalian TM, Ho AM, Burgeon E, Lane WS, Lambert JN, Curran T, Verdine GL, Rao A, Hogan PG 1993. Isolation of the cyclosporin-sensitive $\mathrm{T}$ cell transcription factor NFATp. Science 262: 750-754.

McCaffrey PG, Goldfeld AE, Rao A 1994. The role of NFATp in cyclosporin A-sensitive tumor necrosis factor-a gene transcription. J Biol Chem 269: 3044530450.

Nakajima H, Sano H, Nishimura T, Yoshida S, Iwamoto I 1994. Role of vascular cell adhesion molecule 1/ very late activation antigen 4 and intercellular adhesion molecule $1 /$ lymphocyte function-associated 1 interactions in antigen-induced eosinophil and T cell recruitment in the tissue. J Exp Med 179: 1145-1154.

Nolan GP 1994. NF-AT-AP-1, Rel-bZIP: hybrid vigor and binding under the influence. Cell 77: 795-798.

Northrop JP, Ho SN, Chen L, Thomas DJ, Timmerman LA, Nolan GP, Admon A, Crabtree GR 1994. NF-AT components define a family of transcription factors targeted in T-cell activation. Nature 369: 497-502.

Pare PD, Bai TR 1995. The consequences of chronic allergic inflammation. Thorax 50: 328-332.

Park J, Takeuchi A, Sharma S 1996. Characterization of 
a new isoform of the NFAT (nuclear factor of activated T cells) gene family member NFATc. $J$ Biol Chem 34: 29014-29021.

Paul WE, Seder RA 1994. Lymphocyte responses and cytokines. Cell 76: 241-251.

Perkins D, Wang Z, Donovan C, He H, Mark D, Guan G, Wang Y, Walunas T, Bluestone J, Listman J, Finn PW 1996. Regulation of CTLA-4 expression during T cell activation. $J$ Immunol 156: 4154-4159.

Peters SP 1990. Mast cells and histamine in asthma. $J$ Allergy Clin Immunol 86: 642-646.

Ponath PD, Qin S, Ringler DJ, Clark-Lewis I, Wuang J, Kassam N, Smith H, Shi X, Gonzalo JA, Newman $\mathrm{W}$ et al. 1996. Cloning of the human eosinophil chemoattractant eotaxin. J Clin Invest 97: 604-612.

Pretolani M, Ruffie C, Silva JRD, Joseph D, Lobb RR, Vergaftig BB 1994. Antibody to very late activation antigen 4 prevents antigen-induced bronchial hyperreactivity and cellular infiltration in the guinea pig airways. J Exp Med 180: 795-805.

Prieschl EE, Gouilleux-Gruart V, Walker C, Harrer NE, Baumruker T 1995a. A nuclear factor of activated T cell-like transcription factor in mast cells is involved in IL-5 gene regulation after IgE plus antigen stimulation. J Immunol 154: 6112-6119.

Prieschl EE, Pendl GG, Harrer NE, Baumruker T 1995b. p21ras links FceRI to NF-AT family member in mast cells: the AP3-like factor in this cell type is an NFAT family member. J Immunol 155: 4963-4970.

Randak C, Brabletz T, Hergenröther M, Sobotta I, Serfling E 1990. Cyclosporin A suppresses the expression of the interleukin 2 gene by inhibiting the binding of lymphocyte-specific factors to the IL-2 enhancer. EMBO J 9: 2529-2536.

Rao A 1994. NF-ATp: a transcription factor required for the coordinate induction of several cytokine genes. Immunol. Today 15: 274-281.

Rao A, Luo C, Hogan PG 1997. Transcription factors of the NFAT family: regulation and function. Ann Rev Immunol 15: 707-747.

Romagnani S 1995. Technological advances and new insights into pathogenesis prelude novel therapeutic strategies. Curr Opin Immunol 7: 745-750.

Rooney JW, Sun Y-L, Glimcher LH, Hoey T 1995a. Novel NFAT sites that mediate activation of the interleukin-2 promoter in response to T-cell receptor stimulation. Mol Cell Biol 15: 6299-6310.

Rooney JW, Hoey T, Glimcher LH 1995b. Coordinate and cooperative roles for NFAT and AP-1 in the regulation of the murine IL-4 gene. Immunity 2: 473-483.

Rothenberg ME, MacLean JA, Pearlman E, Luster AD, Leder P 1997. Targeted disruption of the chemokine eotaxin partially reduces antigen-induced tissue eosinophilia. J Exp Med 185: 785-790.

Ruff VA, Leach KL 1995. Direct demonstration of NFATp dephosphorylation and nuclear localization in activated HT-2 cells using a specific NFATp polyclonal antibody. J Biol Chem 260: 22602-22607.

Sanderson CJ, Warren DG, Strath M 1985. Identification of a lymphokine that stimulates eosinophil diffrentiation in vitro. Its relationship to interleukin 3 , and functional properties of eosinophils produced in cultures. J Exp Med 162: 60-74.

Sarafi MN, Garcia-Zepeta EA, MacLean JA, Charo IF, Luster AD 1997. Murine monocyte chemoattractant protein (MCP)-5: a novel CC chemokine that is a structural and functional homologue of human MCP1. J Exp Med 185: 99-109.

Schubert LA, King G, Cron RQ, Lewis DB, Aruffo A, Hollenbaugh D 1995. The human gp39 promoter. $J$ Biol Chem 270: 29624-29627.

Sehmi R, Wardlaw AJ, Cromwell O, Kurihara K, Waltmann P, Kay AB 1992. Interleukin-5 selectively enhances the chemotactic response of eosinophils obtained from normal but not eosinophilic subjects. Blood 79: 2952-2959.

Serfling E, Avots A, Neumann M 1995. The architecture of the interleukin-2 promoter: a reflection of T lymphocyte activation. Biochem Biophys Acta 1263: 181-200.

Shaw JP, Utz PJ, Durand DB, Toole JJ, Emmel EA, Crabtree GR 1988. Identification of a putative regulator of early T cell activation genes. Science 241: 202-205.

Shaw KTY, Ho AM, Raghavan A, Kim J, Jain J, Park J, Sharma S, Rao A, Hogan PG 1995. Immunosuppressive drugs prevent a rapid dephosphorylation of the transcription factor NFAT1 in stimulated immune cells. Proc Natl Acad Sci USA 92: 11205-11209.

Sullivan S, Broide DH 1996. Compartimentalization of eosinophil granulocyte-macrophage colony-stimulating factor expression in patients with asthma. $J$ Allergy Clin Immunol 97: 966-976.

Takatsu K, Tominaga A, Harada N, Mita S, Matsumoto M, Takahashi T, Kikuchi Y, Yamaguchi N 1988. T cell-replacing factor (TRF)/interleukin 5 (IL-5): molecular and functional properties. Immunol Rev 102: 107-135.

Tsai EY, Jain J, Pesavento PA, Rao A, Goldfeld AE 1996. Tumor necrosis factor alpha gene regulation in activated T cells involves ATF-2/Jun and NFATp. Mol Cell Biol 16: 459-467.

Tsytsykova AV, Tsitsikov EN, Geha RS. 1996 The CD40L promoter contains nuclear factor of activated $\mathrm{T}$ cells-binding motifs which require AP-1 binding for activation of transcription. J Biol Chem 271: 3763-3770.

Ullman KS, Flanagan WM, Edwards CA, Crabtree GR 1991. Activation of early gene expression in T lymphocytes by Oct-1 and an inducible protein, OAP40. Science 254: 558-562.

Venkataraman L, Francis DA, Wang Z, Liu J, Rothstein TL, Sen R 1994. Cyclosporin A-sensitive induction of NF-AT in murine B cells. Immunity 1: 189-196.

Wagner C, Gundel R, Reily P, Haynes N, Letts L, Rothlein R 1990. Intercellular adhesion molecule-1 (ICAM-1) in the pathogenesis of asthma. Science 247: 456-459.

Wang DZ, McCaffrey PG, Rao A 1995. The cyclosporinsensitive transcription factor NFATp is expressed in several classes of cells in the immune system. Ann N Y Acad Sci 766: 182-194.

Wardlaw AJ, Symon FS, Walsh GM 1994. Eosinophil adhesion in allergic inflammation. J Allergy Clin 
Immunol 94: 1163-1171.

Warren DJ, Moore MAS 1988. Synergism among interleukin 1, interleukin 3 and interleukin 5 in the production of eosinophils from primitive hemopoietic stem cells. J Immunol 140: 94-99.

Warringa RAJ, Mengelers HJJ, Kuijper PHM, Raaijmakers JAM, Bruijnzeel PBL, Koenderman L 1992. In vivo priming of platelet-activating factorinduced eosinophil chemotaxis in allergic asthmatic individuals. Blood 79: 1836-1841.

Weiss A, Littman DR 1994. Signal transduction by lymphocyte antigen receptors. Cell 76: 263-274.

Weiss DL, Hural J, Tara D, Timmerman LA, Henkel G, Brown MA 1996. Nuclear factor of activated T cells is associated with a mast cell interleukin 4 transcription complex. Mol Cell Biol 16: 228-235.

Weller PF, Rand TH, Goelz SE, Chi-Rosso G, Lobb RJ 1991. Human eosinophil adherence to vascular endothelium mediated by binding VCAM-1 and ELAM-1. Proc Natl Acad Sci USA 88: 7430-7435.
Weller PF 1993. Lipid, peptide and cytokine mediators elaborated by eosinophils, p. 25-42. In H Smith, RM Cook (eds.), Immunopharmacology of Eosinophils. Academic Press Incorporated, London.

Wu J, Katzav S, Weiss A 1995. A functional T-cell receptor signaling pathway is required for $\mathrm{p} 95 \mathrm{vav}$ activity. Mol Cell Biol 15: 4337-4346.

Yamaguchi Y, Suda T, Suda J, Eguchi M, Miura Y, Harada N, Tominaga A, Takatsu K 1988. Purified interleukin 5 supports the terminal differentiation and proliferation of murine eosinophilic precursors. J Exp Med 167: 43-56.

Yaseen NR, Maizel AL, Wang F, Sharma S 1993. Comparative analysis of NFAT (nuclear factor of activated T cells) complex in human T and B lymphocytes. J Biol Chem 268: 14285-14293.

Xanthoudakis S, Viola JPB, Shaw KTY, Luo C, Wallace JD, Bozza PT, Curran T, Rao A 1996. An enhanced immune response in mice lacking the transcription factor NFAT1. Science 272: 892-895. 